\title{
Aktualizace empirických vztahů pro výpočet výparu z vodní hladiny na základě pozorování výparu ve stanici Hlasivo
}

\section{PETRA ŠUHÁJKOVÁ, ROMAN KOŽíN, ADAM BERAN, EVA MELIŠOVÁ, ADAM VIZINA, MARTIN HANEL}

Klíčová slova: výpar - srovnávací výparoměr - výparoměrná stanice Hlasivo - výparoměrná stanice Tišice - odvození regresních vztahů

\section{SOUHRN}

Výpar z vodní hladiny je jednou ze základních složek oběhu vody v prírodě a významně ovlivňuje celkovou hydrologickou bilanci povodí. Vzhledem ke komplikovanému prímému měření je často zjištován ze vzorců, které jako vstupní data vyžadují dostupné měěené meteorologické veličiny.

$\checkmark$ príspěvku je popsán způsob odvození regresních vztahů pro výpočet výparu ve stanici Hlasivo. Dále jsou uvedeny nově odvozené vzorce pro tuto lokalitu, které kombinují různé meteorologické veličiny. Nejlepších výsledků bylo dosaženo při použití vzorce využívajícího k výpočtu globální sluneční radiaci a teplotu vody a vzorec založený na kombinaci teploty vody, relativní vlhkosti vzduchu a teploty vzduchu (popř. rychlosti větru).

Hodnocení vzorců bylo provedeno na základě nejnižší hodnoty průměrné relativní chyby (MRE) a nejvyšší hodnoty Kling-Gupta efficiency (KGE). Vzorce byly testovány na historické datové sadě ze zrušené výparoměrné stanice Tišice. Výsledky ukazují, že pro výpočet výparu pro jinou lokalitu je vhodnější využít vzorce, které se zakládají na jednoduché párové regresi s jednou meteorologickou veličinou (teplotou vody, nebo teplotou vzduchu), na rozdíl od vzorců využívající vícenásobné regrese. Při použití vzorců je vždy nutné ověrit rozsah jejich platnosti.

\section{ÚVOD}

Výpar z vodní hladiny je důležitým členem hydrologické bilance vodních nádrží. V posledních letech je význam výparu z volné hladiny navíc umocňován dopady klimatických změn. Zvyšování průměrné teploty vzduchu má za následek zvýšený úbytek vody výparem, nicméně tyto ztráty nejsou kompenzovány srážkovými úhrny, které jsou víceméně stejné a nerovnoměrně rozdělené. Na území České republiky se proto vyskytují oblasti, kde potenciální evapotranspirace významně převyšuje srážkové úhrny, viz obr. 1. Na povodích s vyšším zastoupením vodních ploch, případně při určování bilance vodních nádrží, je zapotřebí přesné určení výparu z vodní plochy.

Přímé měření výparu je komplikované a není tak časté. Běžná výparoměrná zařízení (např. GGI, Class-A-pan aj.) neudávají výpar, ale tzv. výparnost, která bývá zpravidla vyšší než skutečný výpar [1]. Z tohoto důvodu je výpar vodních nádrží odhadován na základě tabulkových hodnot podle nadmořské výšky [2] nebo určován z matematických vzorců, které obsahují snadněji měřitelné veličiny [3]. Závislost výparu na jednotlivých meteorologických veličinách je popsán českou [4,5] i zahraniční literaturou [6-8].
V článku Berana a kol. [4] byly odvozeny empirické vztahy pro výpočet výparu z vodní plochy na základě dat ze stanice Hlasivo za období 1957-2012. Od té doby se průměrná teplota vzduchu stále zvyšovala a navíc se vyskytly roky s extrémně nízkými srážkovými úhrny $(2015,2018)$. To přispělo k potřebě aktualizování vztahů pro výpočet výparu z vodní hladiny se zahrnutím těchto skutečností.

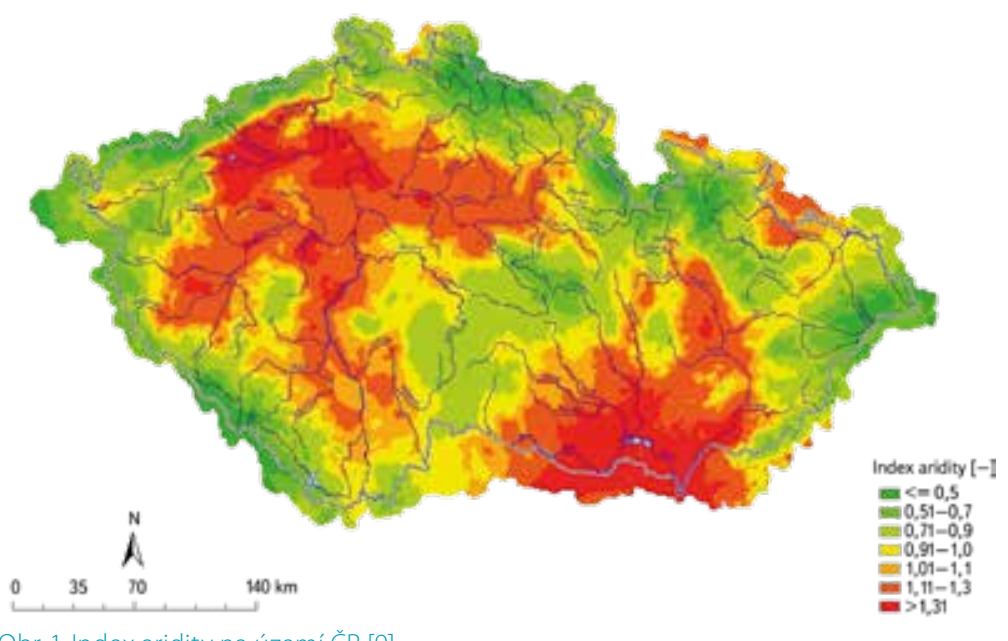

Obr. 1. Index aridity na území ČR [9]

Fig. 1. Aridity index in the Czech Republic [9]

\section{VÝCHOZÍ DATA}

K odvození nových regresních vztahů pro výpočet výparu byla použita data z výparoměrné stanice $v$ Hlasivu u Tábora, $547 \mathrm{~m}$ n. m. K letošnímu roku tak máme díky nepřetržitému fungování stanice 62letou datovou řadu. Jedná se nejen o hodnoty výparu, ale i další meteorologické veličiny, jež stanice zaznamenává.

Vzhledem k tomu, že naměěené denní hodnoty výparu bývají zatížené značnou náhodnou chybou [10], byla k odvozování používána data prưměrného denního výparu $v$ měsíci. $K$ dispozici byly pozorované měsíční řady: teplota vzduchu ve $2 \mathrm{~m}\left[{ }^{\circ} \mathrm{C}\right]$, teplota hladiny vody ve výparoměru $\left[{ }^{\circ} \mathrm{C}\right]$, relativní vlhkost vzduchu [\%], globální sluneční radiace [W/m²] a rychlost větru [m/s]. Výpar byl měřen srovnávacím výparoměrem o ploše hladiny cca $20 \mathrm{~m}^{2}$. Vzhledem $\mathrm{k}$ ploše srovnávacího výparoměru se naměřená výparnost považuje za reálný výpar. 
Sezona měření výparu ve stanici Hlasivo je od května do řijna. V případě nízkých teplot (zamrzání vody ve výparoměru) může začít později nebo být ukončena o několik dní dřive. V takových prípadech jsou pro vyhodnocování vztahů a korelačních koeficientů výparu s vybranými meteorologickými veličinami data zkrácena tak, aby korespondovala s konkrétními dny, kdy se výpar měřil.

\section{VZTAH VÝPARU K VYBRANÝM METEOROLOGICKÝM VELIČINÁM}

Spolu s průběhem výparu v čase byl zpracován i průběh teploty vzduchu a teploty hladiny vody ve výparoměru, viz obr. 2 .

Z obr. 2 a 3 je patrná vzájemná korelace mezi hodnotou výparu a teplotou vzduchu (korelační koeficient $r=0,854$ ), závislost nejlépe vystihuje mocninná funkce $s$ koeficientem determinace $R^{2}=0,752$.

Závislost výparu na teplotě vody nejlépe vystihuje exponenciální funkce na obr. 4 s R² =0,819 a r =0,886.

Výpar z vodní hladiny nejvíce koreluje s globální sluneční radiací $(r=0,914)$ a jejich vztah nejlépe vystihuje mocninná funkce $\left(R^{2}=0,884\right)$, viz obr. 5 .

Výpar s relativní vlhkostí vzduchu vykazuje závislost neprímo úměrnou $(r=-0,644)$. Tuto závislost nejlépe vystihuje lineární funkce $\left(R^{2}=0,411\right)$ viz obr. 6 .

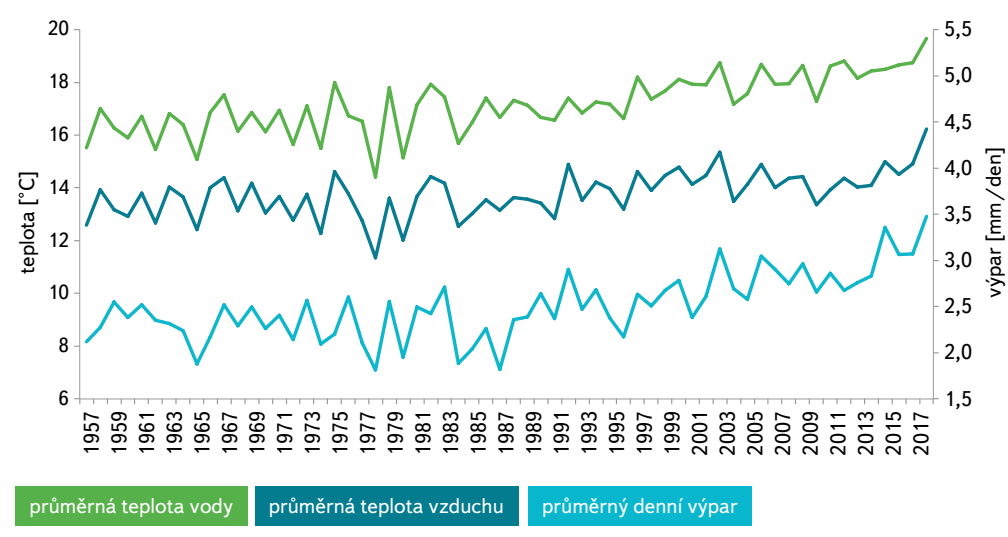

Obr. 2. Průběh průměrné denní hodnoty výparu, průměrné teploty vzduchu a vody ve stanici Hlasivo (květen-ř́ijen)

Fig. 2. Average daily evaporation, average air and water temperature in Hlasivo station (May-October)

\section{METODIKA ODVOZOVÁNÍ VZORCŮ}

Vzhledem k tomu, že některé veličiny nebyly měřeny od začátku pozorování (vítr, globální sluneční radiace), byly zvoleny dva časové úseky (1957-2018 a 2006-2018), ze kterých byly vzorce odvozovány. Nejprve byly určeny párové závislosti průměrného denního výparu z vodní hladiny ( $v$ měsičním kroku) na jednotlivých meteorologických veličinách. Regresní analýzou byla určena rovnice. Pomocí takto získaných rovnic byl vypočítán výpar.

Následně byly spočteny odchylky (rezidua) vypočítaného výparu od pozorovaného (naměřeného). V následujícím kroku byla regresí vyjádřena závislost vypočítaných reziduí na další meteorologické veličině. Kombinací dvou regresních vztahů došlo k vytvoření nového vzorce pro výpočet výparu, do kterého vstupuji dvě meteorologické veličiny. Tento vzorec byl následně rozšiřen o další veličinu, a to stejným způsobem. Z vypočítaného výparu byla spočtena rezidua od výparu pozorovaného. Na základě závislosti další meteorologické veličiny s těmito rezidui byl zkombinován nový vzorec.
Výše popsaným postupem byly vytvořeny desítky vzorců z datové rady Hlasivo 2006-2018, které kombinují veličiny: globální sluneční radiace, teplota vzduchu a vody, relativní vlhkost vzduchu a rychlost větru. Dále bylo vytvořeno několik vzorců z nejdelší možné datové řady, které kombinují teplotu vody a vzduchu (1957-2018) a relativní vlhkost vzduchu (1965-2018).

Vhodnost vzorců byla hodnocena na základě průměrné relativní chyby (MRE) a hodnoty Kling-Gupta efficiency (KGE) [11]. Závislosti výparu na datech z let 1957-2018 vykazují vyšší MRE a nižší KGE, jsou ovšem platné pro širší rozsah hodnot. Na základě nejvyšších hodnot KGE a nejnižších hodnot MRE v jednotlivých datových řadách byl zúžen výběr vzorců na 16, viz tabulka 1 .

\section{VÝSLEDKY A DISKUSE}

Tabulka 1 uvádí výběr vzorců pro výpočet výparu z vodní hladiny. První sloupec značí datovou řadu, ze které daný vzorec vznikl. V prípadě, že byl vzorec z delší datové řady kombinován s relativní vlhkostí vzduchu, je výpočet aplikován pouze na data od roku 1965.

Nejlepší shody vypočteného a měřeného výparu na základě KGE je dosaženo při použití odvozených vztahů se zastoupením měřených meteorologických veličin: teplota vody, relativní vlhkost vzduchu a rychlost větru (vzorec E5, MRE $=12,31 \%$, $K G E=0,937)$. Nejnižší hodnotu MRE vykazuje vzorec E2, do kterého vstupují veličiny: globální sluneční radiace a teplota vzduchu (MRE =11,08\%, KGE =0,892). V obou případech se jedná o vzorce vzniklé z datové řady Hlasivo 2006-2018.

výpočet výparu na základě vzorců vzniklých z delší datové sady odpovídá nejlépe při použití vzorce E15, který kombinuje teplotu vody a relativní vlhkost vzduchu (MRE $=13,24 \%, \mathrm{KGE}=0,907)$ a vzorce E14, kombinující teplotu vody, relativní vlhkost vzduchu a teplotu vzduchu (MRE $=13,20 \%, \mathrm{KGE}=0,857$ ). Průběh výparu vypočteného podle vybraných vzorců je znázorněn na obr. 7 .

\section{Validace vzorců}

Všechny vytvořené vzorce byly validovány na datové řadě Hlasivo 1999-2005. K dispozici byly všechny veličiny, které vstupuji do odvozených vzorců. U globální sluneční radiace není datová řada kontinuální. Jedná se o sezonu 1999 a poté 2001-2005. Výsledky testování jsou uvedeny v tabulce 1, sloupec "1999-2005“. Průběh naměřeného a vypočteného výparu je zobrazen na obr. 8. Maximální a minimální hodnoty veličin uvádí tabulka 2.

Z výsledků vyplývá, že nejlepší shody vypočteného a naměřeného výparu na základě nejnižší hodnoty MRE je dosaženo při použití vzorce založeného na lineárním vztahu s globální sluneční radiací a teplotou vody (vzorec E3, MRE = 10,38 \%, KGE $=0,905)$. Z hodnocení na základě KGE vyplývá, že nejlepší vzorec k výpočtu výparu je vztah založený na kombinaci teploty vody, relativní vlhkosti vzduchu a teploty vzduchu (vzorec E14, MRE $=11,51 \%, \mathrm{KGE}=0,933$ ).

Obecně Ize říci, že z hodnocení na základě KGE se jako významná veličina vstupující do výpočtu výparu prokázala teplota hladiny vody. Přičemž, je vhodnějši využívat vzorců z delší datové řady, jelikož jsou robustnější a mají širší rozsah platnosti, viz tabulka 2. Hodnota KGE u vzorců vycházejících z teploty vody se pohybuje mezi 0,85-0,93.

Z hodnocení na základě MRE se jako nejvýznamnější veličina vstupující do vzorců prokázala globální sluneční radiace. U takovýchto vzorců se MRE pohybuje mezi 10,4-12,7\%. Vzorce využívající k výpočtu globální sluneční radiaci jsou k dispozici pouze z datové řady 2006-2018.

Všechny vzorce byly také aplikovány na datové řadě ze zrušené výparoměrné stanice Tišice u Neratovic, 163 m n. m. (1957-1974). V Tišicích byla rychlost větru ve 2 m měřena od roku 1959 a globální sluneční radiace zde nebyla měřena vůbec. Pro srovnání vypočteného výparu s naměřeným byly použity hodnoty ze srovnávacího výparoměru o stejné ploše jako v Hlasivu. Sezona 


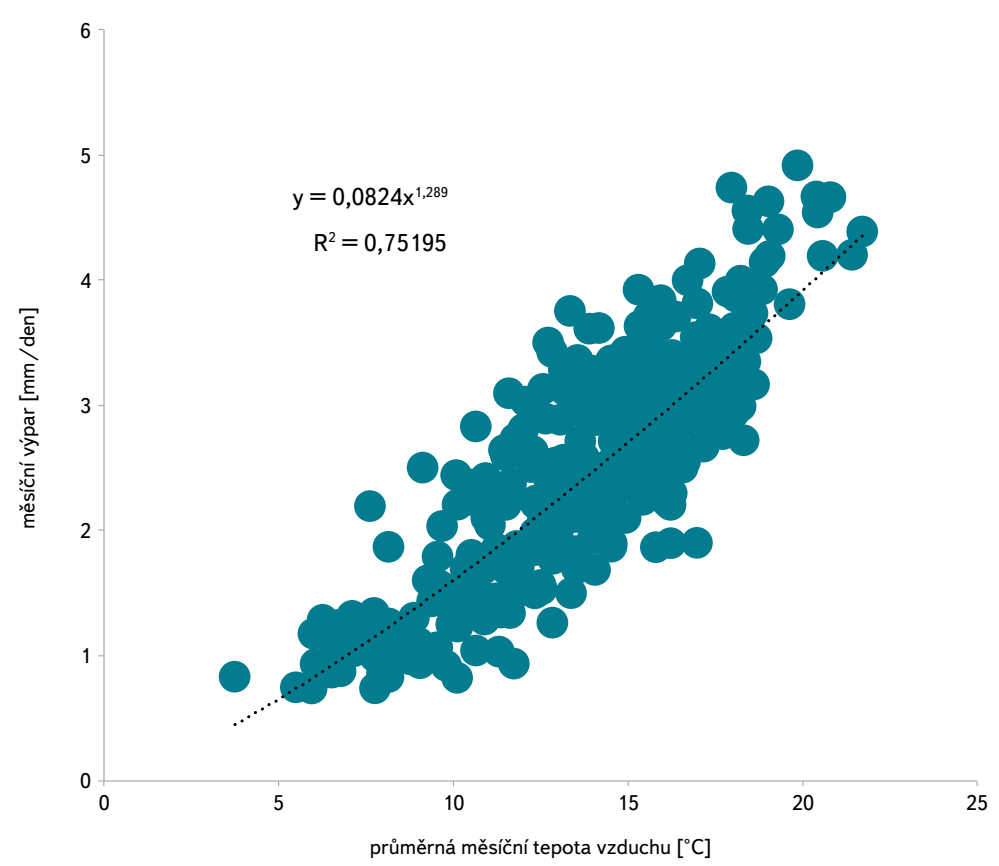

Obr. 3. Vztah mezi prưměrnou měsiční teplotou vzduchu a výparem od roku 1957-2018 Fig. 3. Relationship between average monthly air temperature and evaporation from 1957-2018

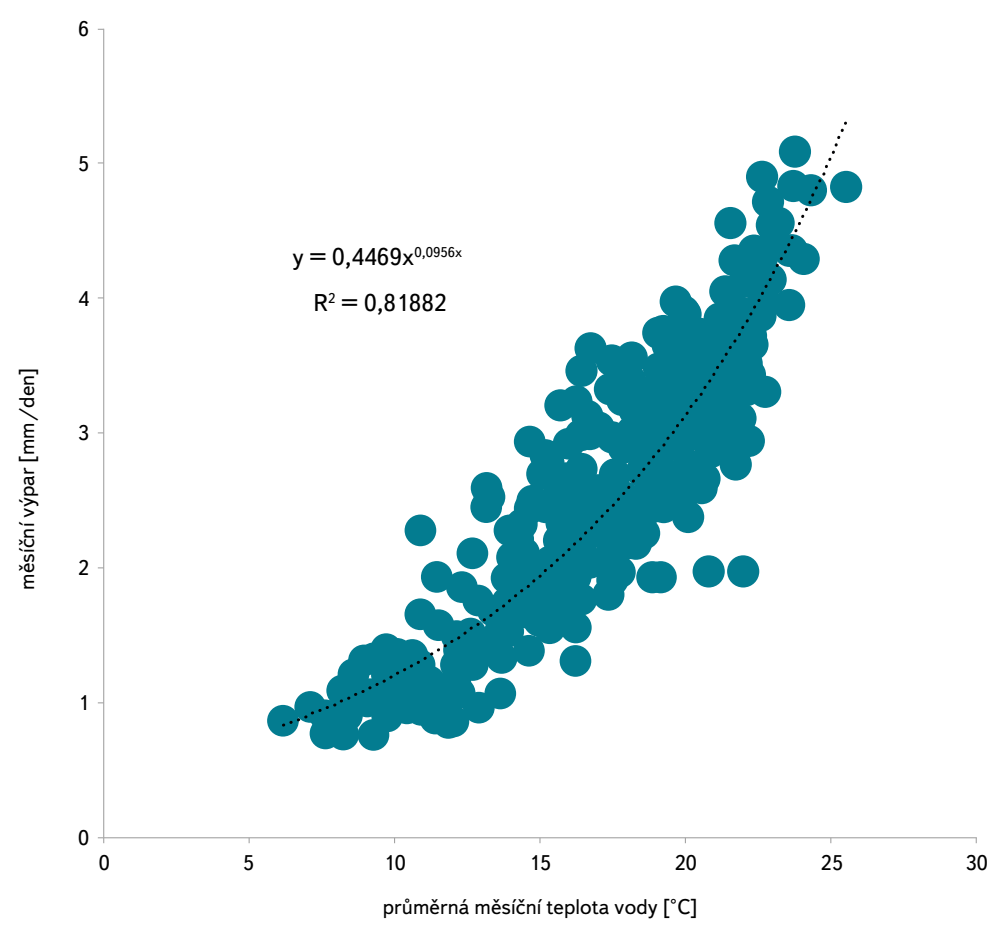

Obr. 4. Vztah mezi průměrnou měsiční teplotou vody ve výparoměru a výparem od roku 1957-2018

Fig. 4. Relationship between average monthly water temperature in evaporimeter and evaporation from 1957-2018

pro měěení výparu v Tišicích byla od dubna do řijna. Výpar byl počítán pouze pro rozsah hodnot platný pro rovnice odvozené z Hlasiva v období 1957-2018. Při ponechání minimálních hodnot se projevil rozsah platnosti vzorců, proto některé výpočty udávaly nereálné hodnoty.

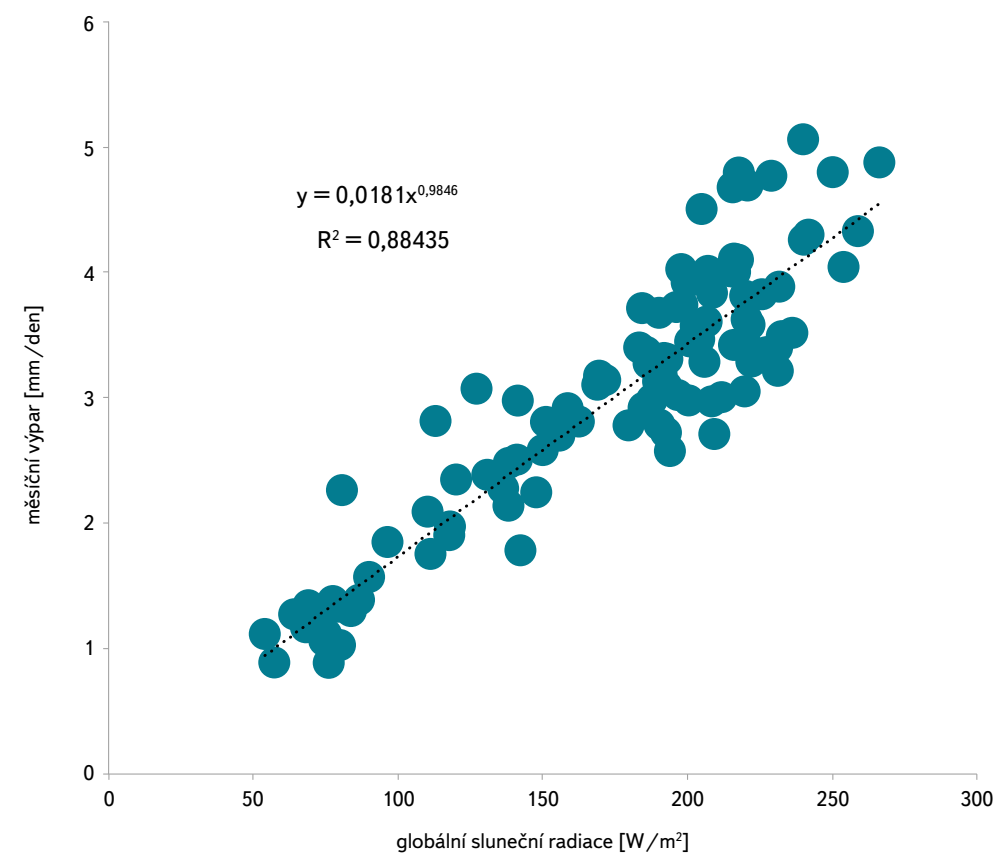

Obr. 5. Závislost výparu z vodní hladiny na globální sluneční radiaci (1999-2018) Fig. 5. The dependence of evaporation from water surface on global solar radiation (1999-2018)

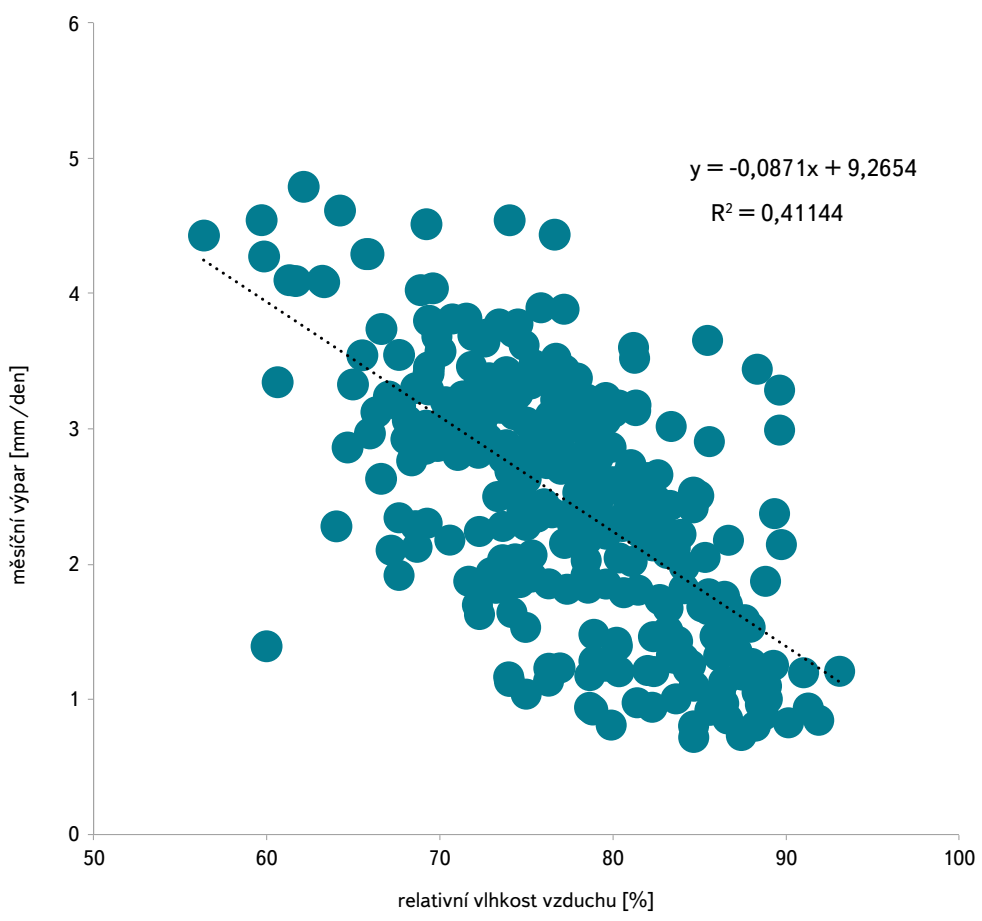

Obr. 6. Vztah mezi průměrnou relativní vlhkostí vzduchu a výparem od roku 1965-2018

Fig. 6. Relationship between average relative air humidity and evaporation from 1965-2018

Výsledky testování jsou uvedeny v tabulce 1, sloupec "Tišice". Průběh výparu je zobrazen na obr. 9. Nejlepší shody vypočteného a naměřeného výparu na základě hodnoty MRE je dosaženo při použití vzorce E6, založeného na vztahu s teplotou vody a rychlosti větru (MRE $=18,8 \%, K G E=0,755)$. Z hodnocení na 
Tabulka 1. Výběr vzorcui pro výpočet výparu a jejich hodnoceni na základě MRE a KGE

Table 1. The formulas for calculating evapotration and their evaluation based on MRE and KGE

\begin{tabular}{|c|c|c|c|c|c|c|c|c|c|c|c|}
\hline \multirow{2}{*}{$\begin{array}{l}\text { Datová } \\
\text { sada }\end{array}$} & \multirow{2}{*}{ Zn. } & \multirow{2}{*}{ Veličiny } & \multirow{2}{*}{ Vzorec } & \multicolumn{2}{|c|}{$57(65)-18$} & \multicolumn{2}{|c|}{ 2006-2018 } & \multicolumn{2}{|c|}{ 1999-2005 } & \multicolumn{2}{|c|}{ Tišice } \\
\hline & & & & MRE & KGE & MRE & KGE & MRE & KGE & MRE & KGE \\
\hline $06-18$ & E1 & $\mathrm{R}$ & $0,0157^{*} \mathrm{R} \wedge 1,0148$ & & & 0,12 & 0,89 & 0,10 & 0,89 & & \\
\hline 06-18 & E2 & R Tvzd & $0,0169 * R+0,0369 * T v z d-0,002 * R-0,1536$ & & & 0,11 & 0,89 & 0,11 & 0,90 & & \\
\hline $06-18$ & E3 & R TV & $0,0157^{*} R \wedge 1,0148+0,0209^{*} T v-0,0017^{*} R-0,069$ & & & 0,11 & 0,89 & 0,10 & 0,90 & & \\
\hline $06-18$ & E4 & Tv & $0,032^{*} \operatorname{T\vee } 1,5401$ & 0,16 & 0,88 & 0,14 & 0,88 & 0,15 & 0,89 & 0,33 & 0,60 \\
\hline 06-18 & E5 & TV HV & $0,032^{*}(\operatorname{T\vee } \wedge 1,5401)-1,763^{*} \ln (H)+0,611^{*} \vee-1,3498$ & & & 0,12 & 0,94 & 0,12 & 0,93 & 0,24 & 0,67 \\
\hline 06-18 & E6 & TV V & $0,4834^{*} \exp \left(0,0936^{*} \mathrm{TV}\right)+0,7129^{*} \vee-1,0594$ & & & 0,14 & 0,89 & 0,14 & 0,82 & 0,19 & 0,76 \\
\hline $06-18$ & E7 & TV V H & $\begin{array}{l}0,4834^{*} \exp \left(0,0936^{*} T v\right)+0,7129^{*} V- \\
-1,9686^{*} \mathrm{H}+0,4706\end{array}$ & & & 0,13 & 0,92 & 0,12 & 0,92 & 0,21 & 0,70 \\
\hline $57-18$ & E8 & Tvzd & $0,0824^{*} \operatorname{Tvzd} \wedge 1,289$ & 0,17 & 0,78 & 0,17 & 0,73 & 0,17 & 0,81 & 0,28 & 0,76 \\
\hline 57-18 & E9 & Tvzd & $0,5267^{*} \exp \left(0,1073^{*} \operatorname{Tv} z\right)$ & 0,16 & 0,83 & 0,17 & 0,82 & 0,17 & 0,84 & 0,30 & 0,65 \\
\hline $57-18$ & E10 & TV & $0,0407^{*} \operatorname{TV} \wedge 1,4366$ & 0,14 & 0,82 & 0,15 & 0,78 & 0,14 & 0,85 & 0,27 & 0,75 \\
\hline 57-18 & E11 & TV & $0,4469^{*} \exp \left(0,0956^{*} T v\right)$ & 0,14 & 0,87 & 0,14 & 0,88 & 0,14 & 0,89 & 0,29 & 0,63 \\
\hline $57-18$ & E12 & Tv Tvzd & $0,4469^{*} \exp \left(0,0956^{*} T v\right)-0,0112^{*} T v z d+0,1869$ & 0,15 & 0,85 & 0,15 & 0,86 & 0,13 & 0,88 & 0,30 & 0,66 \\
\hline $57(65)-18$ & E13 & Tv H & $0,0407^{*} T \vee \wedge 1,4366-2,4396^{*} \mathrm{H}+1,9261$ & 0,14 & 0,90 & 0,12 & 0,89 & 0,13 & 0,91 & 0,28 & 0,68 \\
\hline $57(65)-18$ & E14 & Tv H Tvzd & $\begin{array}{l}0,0407^{*} \operatorname{Tv} \wedge 1,4366-1,893^{*} \ln (H)- \\
0,239^{*} \ln (\operatorname{Tvzd})+0,1645\end{array}$ & 0,13 & 0,86 & 0,12 & 0,85 & 0,12 & 0,93 & 0,29 & 0,73 \\
\hline $57(65)-18$ & E15 & Tv $H$ & $0,4469^{*} \exp \left(0,0956^{*} \mathrm{Tv}\right)-1,8338^{*} \mathrm{H}+1,4425$ & 0,13 & 0,91 & 0,13 & 0,89 & 0,13 & 0,86 & 0,29 & 0,58 \\
\hline $57(65)-18$ & E16 & Tvzd H & $0,0824^{*} \operatorname{Tvzd} \wedge 1,289-2,3265^{*} \mathrm{H}+1,8627$ & 0,16 & 0,86 & 0,15 & 0,84 & 0,16 & 0,88 & 0,31 & 0,70 \\
\hline
\end{tabular}

Vysvětlivky:

$E=$ výpar $[\mathrm{mm} / \mathrm{den}], R=$ průmèrná denní radiace $\left[\mathrm{W} / \mathrm{m}^{2}\right], T \mathrm{v}=$ teplota vody $\left[{ }^{\circ} \mathrm{C}\right], T \mathrm{vzd}=$ teplota vzduchu $\left[{ }^{\circ} \mathrm{C}\right], \mathrm{H}=$ relativni vlhkost vzduchu $[\% / 100], V=$ vítr $[\mathrm{m} / \mathrm{s}]$

Explanatory notes:

$E=$ evaporation $[\mathrm{mm} / \mathrm{den}], R=$ average daily radiation $\left[\mathrm{W} / \mathrm{m}^{2}\right], T \mathrm{~V}=$ water temperature $\left[{ }^{\circ} \mathrm{C}\right], T_{\mathrm{V} z d}=$ air temperature $\left[{ }^{\circ} \mathrm{C}\right], \mathrm{H}=$ relative air humidity $[\% / 100], V=$ air velocity $[\mathrm{m} / \mathrm{s}]$

Tabulka 2. Maximální a minimální hodnoty veličin naměrené ve stanici Hlasivo (měsíční prüměry)

Table 2. Maximum and minimum values, measured in the Hlasivo station (monthly averages)

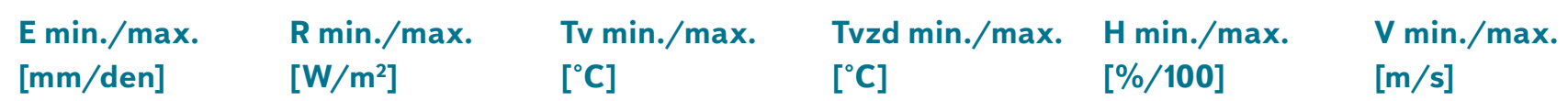

$\left[\begin{array}{lllll}\mathrm{mm} / \mathrm{den}] & {\left[\mathrm{W} / \mathrm{m}^{2}\right]} & {\left[{ }^{\circ} \mathrm{C}\right]} & {\left[{ }^{\circ} \mathrm{C}\right]} & {[\% / 100]}\end{array}\right]$

\begin{tabular}{|c|c|c|c|c|c|c|c|c|c|c|c|c|}
\hline Hlasivo 57-18 & 0,73 & 4,91 & - & - & 6,2 & 25,5 & 3,7 & 21,7 & 0,56 & 0,93 & - & t \\
\hline Hlasivo 06-18 & 0,85 & 4,91 & 57,1 & 266,5 & 9,5 & 25,5 & 6,8 & 21,7 & 0,60 & 0,93 & 0,7 & 2,4 \\
\hline Hlasivo 99-05 & 1,03 & 4,54 & 54,0 & 266,5 & 8,6 & 23,7 & 6,2 & 20,5 & 0,56 & 0,89 & 0,8 & 2,0 \\
\hline
\end{tabular}

Vysvětlivky:

$E=$ výpar, $R$ = globální radiace, $T v=$ teplota vody, Tvzd = teplota vzduchu, $H=$ relativní $v$ lhkost vzduchu, $V=$ rychlost větru

Explanatory notes:

$E=$ evaporation, $R=$ global solar radiation, $T V=$ water temperature, $T_{v} z=$ air temperature, $H=$ relative air humidity, $V=$ air velocity 


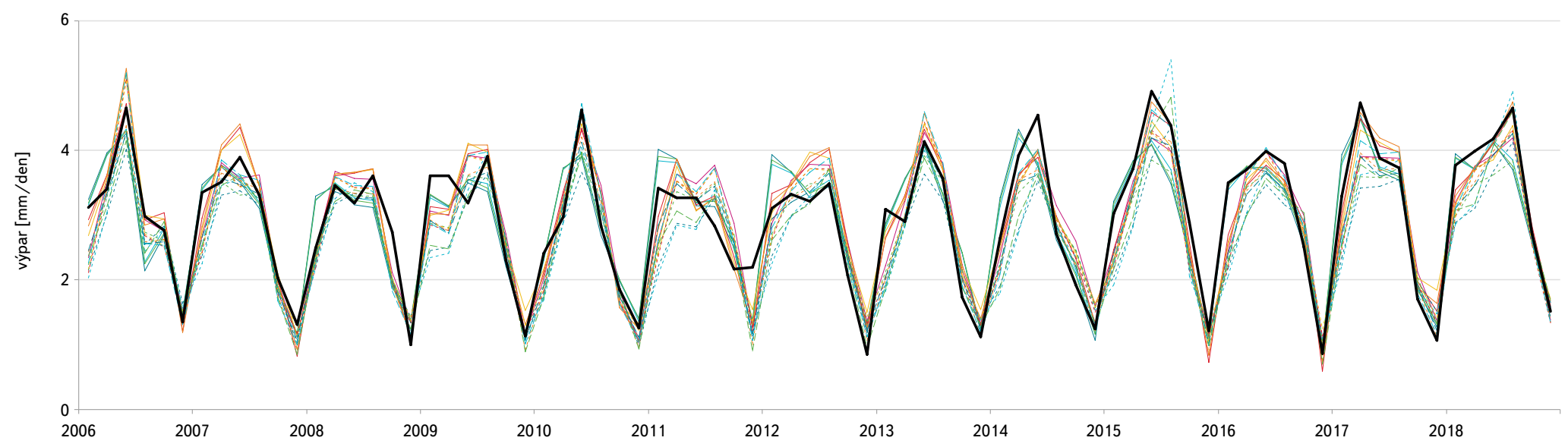

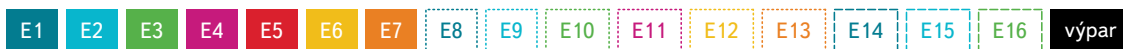

\section{Obr. 7. Průběh naměřeného (černá barva) a vypočteného výparu pro roky 2006-2018}

Fig. 7. Measured (black color) and calculated evaporation for years 2006-2018

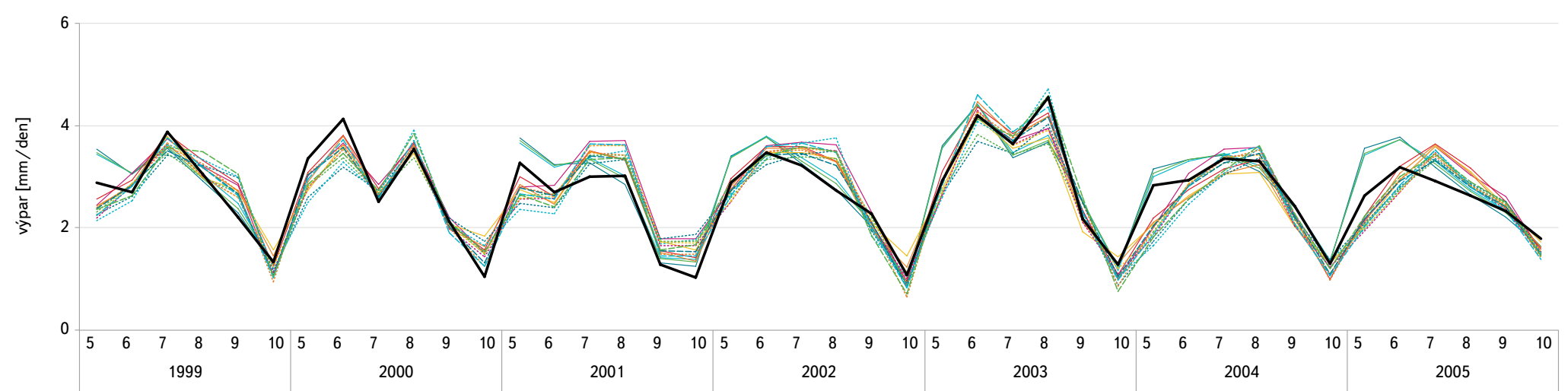

\section{E1 E2 E E E E4 E E}

Obr. 8. Prưběh naměreného výparu (černá barva) a vypočteného výparu pro roky 1999-2005

Fig. 8. Measured evaporation (black color) and calculated evaporation for years 1999-2005

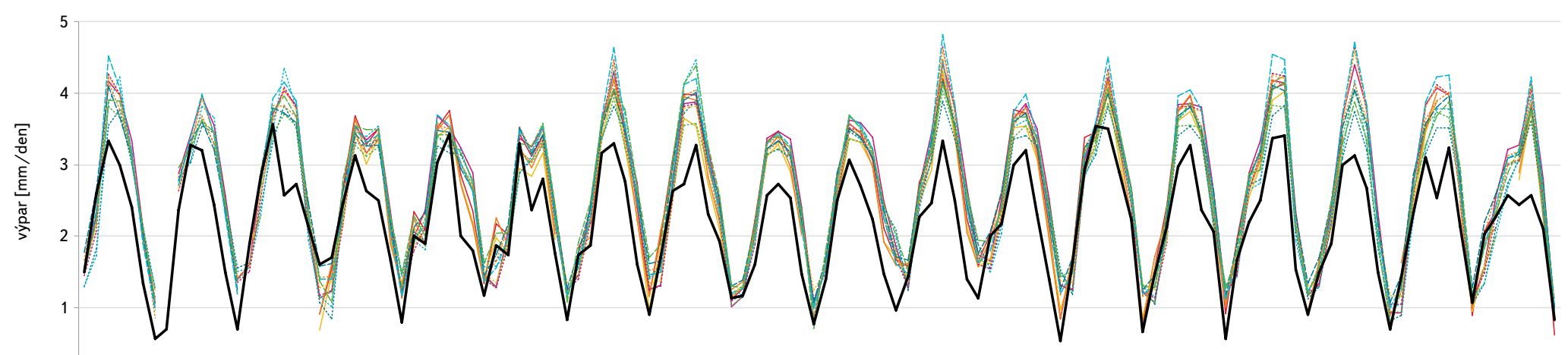

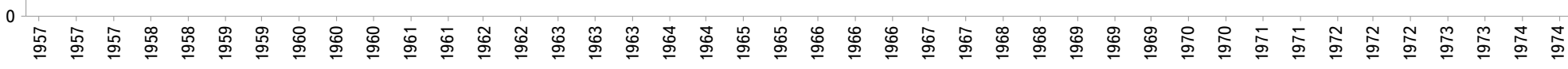

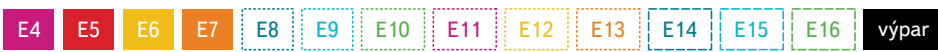




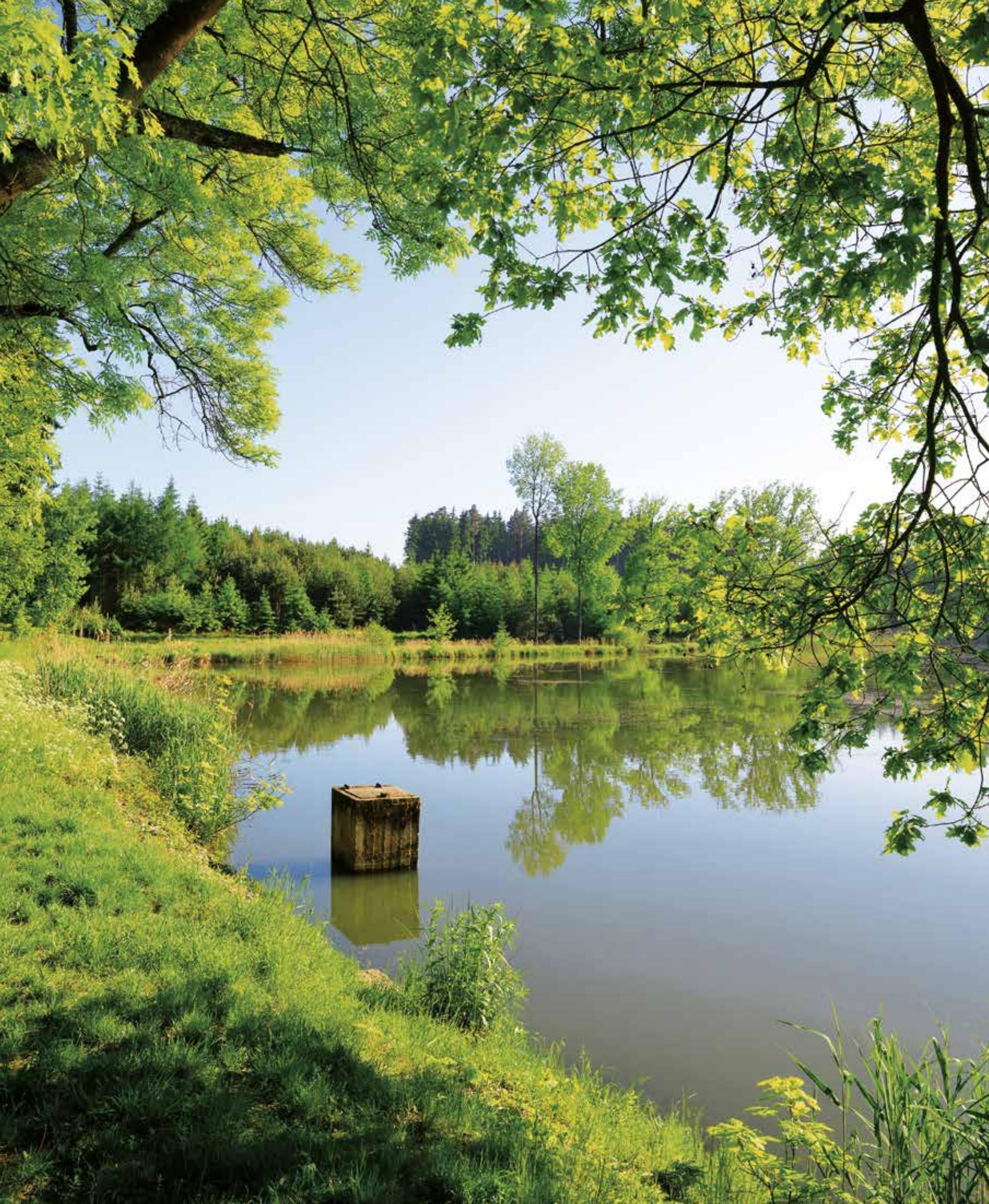


základě KGE vyplývá, že nejlepší vzorec k výpočtu výparu je vztah založený na jednoduché párové regresi s teplotou vzduchu (vzorec E8, MRE $=28,2 \%$, $\mathrm{KGE}=0,756)$

Obecně lze výsledky interpretovat tak, že rychlost větru je významnou veličinou, která zpřesňuje výpočet výparu. Při absenci měření rychlosti větru je vždy lepší použít vzorce vzniklé z delší datové řady, jelikož vykazují vyšší shodu na základě KGE. Dále bylo prokázáno, že jednoduchá párová regrese s teplotou vzduchu, nebo vody je pro výpočet výparu pro stanici Tišice přesnější, než vícenásobné regrese kombinující relativní vlhkost vzduchu.

\section{ZÁVĚR}

Všechny regresní vztahy pro výpočet výparu byly odvozeny na základě dat měřených pouze od května do řijna. Obor platnosti těchto vztahů je definován rozsahem hodnot uvedených $v$ tabulce 2 . Vytvořené vzorce byly validovány na datové řadě Hlasivo 1999-2005 a ověřené na datech ze stanice Tišice 1957-1974.

Pro výpočet výparu ve stanici Hlasivo jsou stěžejní vzorce, které obsahují globální sluneční radiaci, jež vykazují nejnižší MRE, konkrétně vzorec E3. Další stěžejní veličinou je teplota hladiny vody ve výparoměru, predevším v kombinaci s dalšími meteorologickými veličinami, které daný výpočet zpřesňují. Velmi dobře vychází vícenásobná regrese teploty hladiny vody s relativní vlhkostí vzduchu a teplotou vzduchu (vzorec E14), popř. teplota hladiny vody s relativní vlhkostí vzduchu a rychlostí větru (vzorec E5).

Pro výpočet výparu pro stanici Tišice je vhodné využít vzorce z delší datové sady, zakládající se na jednoduché párové regresi s teplotou vody (vzorec E10), anebo vzduchu (vzorec E8), popř. vzorce kombinující teplotu vody a rychlost větru (vzorec E6). Vhodnost využití globální sluneční radiace nebylo možné testovat.

Volba vzorců pro výpočet výparu závisí na dostupnosti jednotlivých meteorologických veličin, přičemž je nutné oveřit i rozsah platnosti jednotlivých vzorců

Pro zpřesnění výpočtů je nutné vzorce validovat na více datových sadách z různých lokalit. Následně vytvořit sady vzorců, které budou využitelné pro lokality s podobnými geografickými charakteristikami. Dá se předpokládat, že vzorce ověřené na stanici Tišice jsou již nyní použitelné pro jiné lokality, avšak uživatel musí počitat s chybou 20-30\%.

V současné době je řešen projekt TJ01000196 Vytvoření softwaru pro výpočet výparu z vodní hladiny pro podmínky ČR, jež má za cíl vytvořit vztahy pro výpočet výparu z vodní hladiny platné na celé území ČR. Řešení bude vycházet z pozorování výparu ve stanici Hlasivo a vybraných výparoměrných stanic ČHMÚ

\section{Poděkování}

Článek vznikl na základě výzkumu prováděného v rámci projektu Technologické agentury ČR TJ01000196 Vytvoření softwaru pro výpočet výparu z vodní hladiny pro podmínky ČR v rámci programu Zéta.

\section{Literatura}

[1] SZEICZ, G. and LONG, I.F. Surface resistance of crop canopies. 1969. p. 122.

[2] ČSN 75 2405. Vodohospodářská řešení vodních nádrží. Praha: Úřad pro technickou normalizaci, metrologii a státní zkušebnictví, 2017. Dostupné také z: http://csnonline.agentura-cas.cz/

[3] ALLEN, R.G., PEREIRA, L.S., REAS, D., and SMITH M. Crop evapotranspiration - Guidelines for computing crop water requirements - FAO Irrigation and drainage paper 56. FAO - Food and Agriculture Organization of the United Nations, Rome, 1998. ISBN 92-5-104219-5.

[4] BERAN, A. a VIZINA, A. Odvození regresních vztahů pro výpočet výparu z volné hladiny a identifikace trendů ve vývoji měřených veličin ve výparoměrné stanici Hlasivo. Vodohospodářské technicko-ekonomické informace, 2013, 55, č. 4.

[5] MOŽNÝ, M. Automatizace měření výparu z volné vodní hladiny. Meteorologické zprávy, 2003, 56, 5, s. $150-155$.

[6] BYCZKOWSKI, A. Hydrologiczne podstawy projektowy wodnomelioracyinych przepływ charakterystyczne. Państwowe Wydawnictwo Rolnicze i Leśne, 1979. 401 s. ISBN 83-09-00035-9.

[7] GASH, J.H.C. and SHUTTLEWORTH, W.J. Evaporation. Wallingford: IAHS Press, 2007. 521 s. ISBN 978-1-901502-98-5.

[8] PENMAN, H.L. Natural evaporation from open water, bare soil and grass. Proc. R. Soc. A., 1948, 193, p. $120-145$.

[9] BUDíK, L. a kol. Odvození základních hydrologických údajů za referenční období 1981-2000. Praha: ČHMÚ, 2015. 35 s.

[10] MRKVIČKOVÁ, M. Vyhodnocení měření na výparoměrné stanici Hlasivo. VTEl, 49/II, př́loha Vodního hospodářství, 2007 č. 6. s. 9-11. ISSN 0322-8916.

[11] GUPTA, HV KLING, H YILMAZ, K K and MARTINEZ, G.F Decomposition of the mean squared error and NSE performance criteria: Implications for improving hydrological modeling. Journal of Hydrology, 2009, vol. 377, No. 1-2, p. 80-9

\section{Autoři}

Mgr. Petra Šuhájková1,2

凶petra.suhajkova@vuv.cz

Ing. Roman Kožín ${ }^{1,2}$

凶roman.kozin@vuv.cz

Ing. Adam Beran, Ph.D. ${ }^{1,2}$

凶adam.beran@vuv.cz

Ing. Eva Melišová

melisovae@fzp.czu.cz

Ing. Adam Vizina, Ph.D.,

凶adam.vizina@vuv.cz

doc. Ing. Martin Hanel, Ph.D.,

凶martin.hanel@vuv.cz

'Výzkumný ústav vodohospodářský T. G. Masaryka, v. v. i.

${ }^{2}$ Fakulta životního prostředí, Česká zemědělská univerzita v Praze

Příspěvek prošel lektorským řízením. 


\section{UPDATE OF EMPIRICAL RELATIONSHIPS \\ FOR CALCULATION OF FREE WATER SUR- \\ FACE EVAPORATION BASED ON OBSER- \\ VATION AT HLASIVO STATION}

\section{SUHAJKOVA, P.,2; KOZIN, R., ${ }^{1,2}$; BERAN, A.,2; \\ MELISOVA, E. ${ }^{2}$; VIZINA, A. ${ }^{1,2}$; HANEL, M. ${ }^{1,2}$}

'TGM Water Research Institute, p.r.i.

${ }^{2}$ Faculty of Environmental Sciences, Czech University of Life Sciences Prague

Keywords: evaporation - evaporation pan -

evaporation station Hlasivo - evaporation station Tišice -

regression analysis

Evaporation from free water surface is one of the essential components of water circulation in nature and significantly affects the overall water balance of the catchment. Due to the complicated direct measurement, it is often calculated from formulas that require available meteorological variables as input data.

The paper describes the method to obtain empirical relations for the estimation of evaporation as functions of available meteorological data in the Hlasivo station. Multiple linear and non-linear regression technique is used for fitting the best model forms. The best results were obtained using the formula based on global solar radiation and water temperature and the formula based on the combination of water temperature, relative air humidity and air temperature (or wind speed).

The formulas were evaluated by mean relative error (MRE) and Kling-Gupta efficiency (KGE). The formulas were validated on a historical data set from the canceled Tišice evaporation station. The results show that it is preferable to use formulas based on simple paired regression with one meteorological variable (water temperature or air temperature) to calculate the evaporation for another site, as opposed to equations obtained by multiple regression. When using empirical formulas, it is always necessary to verify their validity. 